Check for updates

Cite this: RSC Adv., 2018, 8, 23364

\title{
The fundamental roles of monovalent and divalent cations with sulfates on molybdenite flotation in the absence of flotation reagents
}

\begin{abstract}
Yubiao Li, (DD *ab Clement Lartey, ${ }^{\star a}$ Shaoxian Song, ${ }^{a}$ Yingjie Li ${ }^{\mathrm{c}}$ and Andrea R. Gerson ${ }^{d}$
Due to regional shortage of freshwater, the use of saline/seawater for $\mathrm{Cu}$-Mo sulfide ore flotation has received considerable attention. However, the effects of various salts, especially the cations present in seawater, on molybdenite flotation and the mechanisms involved remain unclear due to the complexity of the solutions applied. In this work, the influence of some common cations (i.e., $\mathrm{Na}^{+}, \mathrm{K}^{+}, \mathrm{Ca}^{2+}$ and $\mathrm{Mg}^{2+}$ ) with sulfate $\left(\mathrm{SO}_{4}{ }^{2-}\right)$ anions on molybdenite flotability was investigated in the absence of flotation reagents (i.e., frothers and collectors) at $\mathrm{pH}$ 10. Flotation results indicated a greater depression of molybdenite recovery with increased sulfate salt concentration. The underlying mechanisms responsible for the deleterious effects in the presence of $\mathrm{Na}^{+}$and $\mathrm{K}^{+}$can be attributed to the increased repulsive forces between molybdenite particles and bubbles owing to increased molybdenite oxidation to produce e.g., $\mathrm{MoO}_{4}{ }^{2-}$ and $\mathrm{HMoO}_{4}{ }^{-}$. However, the increased depression observed in the presence of $\mathrm{Mg}^{2+}$ and $\mathrm{Ca}^{2+}$ is likely due to the adsorption of precipitated $\mathrm{Mg}(\mathrm{OH})_{2}$ and $\mathrm{CaMoO}_{4}$, respectively, onto molybdenite surfaces. These clearly show the different depressing mechanisms due to monovalent and divalent sulfates on molybdenite flotation in the absence of

flotation reagents, to reveal the influence of these sulfate salts on its natural flotability.
\end{abstract}

Received 28th March 2018

Accepted 19th June 2018

DOI: $10.1039 / \mathrm{c} 8 \mathrm{ra02690d}$

rsc.li/rsc-advances

\section{Introduction}

Mineral flotation is a water-intensive process consuming vast amounts of freshwater every year. ${ }^{\mathbf{1}}$ The scarcity of freshwater in some arid areas (e.g., Mt Keith and Leinster Mines in Western Australia, Grasberg Mine in Indonesia, Xstrata Nickel Raglan Mine in Canada, Las Luces Mine in Chile) coupled with economic and environmental concerns has prompted alternatives to freshwater. ${ }^{2,3}$ Ideally, saline, seawater or recycled water would serve as sustainable water sources for future flotation processes, especially for those located near the sea and/or lacking freshwater. ${ }^{4,5}$ However, seawater having a salinity of $3.5 \mathrm{wt} \%$ and containing various ions including $\mathrm{Na}^{+}, \mathrm{K}^{+}, \mathrm{Mg}^{2+}$, $\mathrm{Ca}^{2+}, \mathrm{Cl}^{-}$and $\mathrm{SO}_{4}{ }^{2-}$ may affect mineral flotation processes. ${ }^{6}$

Many studies have shown improved mineral recovery in the presence of inorganic electrolytes. ${ }^{7-9}$ For instance, Zhang, et al. ${ }^{\mathbf{1 0}}$ found that seawater modified the network structure of bentonite, enhancing copper and gold recovery. Ozdemir ${ }^{11}$ showed that coal recovery in a salt water system depended on the type and concentration of electrolytes. In addition, the presence of

${ }^{a}$ School of Resources and Environmental Engineering, Wuhan University of Technology, Wuhan, 430070, Hubei, China.E-mail: Yubiao.Li@whut.edu.cn; cle.lartey@yahoo. com

${ }^{b}$ School of Natural and Built Environments, University of South Australia, Mawson Lakes, SA 5095, Australia

'Shaanxi Provincial Academy of Environmental Science, Xi'an, 710061, Shaanxi, China ${ }^{d}$ Blue Minerals Consultancy, Wattle Grove, Tasmania, Australia, 7109 inorganic salts inhibited bubble coalescence, producing a smaller bubble and enhancing sulfide mineral recovery. ${ }^{\mathbf{1 2}}$

The chief source of molybdenum (Mo), molybdenite $\left(\mathrm{MoS}_{2}\right)$, is normally associated with porphyry copper minerals. Enhanced molybdenite recovery has been reported in salt water. ${ }^{4,7,13}$ For instance, Lucay, et al. ${ }^{\mathbf{1 4}}$ reported that $\mathrm{Na}^{+}$ decreased electrostatic repulsion between bubbles and anionic edges of molybdenite, thus improving molybdenite recovery. However, several other studies have reported deleterious effects of saline or seawater on molybdenite flotability, ${ }^{15-18}$ e.g., Raghavan and $\mathrm{Hsu}^{19}$ reported that molybdenite depression in saline or seawater may be caused by the adsorption of hydrolyzed $\mathrm{Ca}^{2+}$ species on molybdenite surface. Recently, Wan, et $a .^{20}$ studied the interactions between $\mathrm{Ca}^{2+}$ and molybdenite edges and found that preferential oxidation of molybdenite edges produced $\mathrm{MoO}_{4}{ }^{2-}$ which made the molybdenite edges negatively charged and attracted $\mathrm{Ca}^{2+}$, leading to the formation of $\mathrm{CaMoO}_{4}$ which was responsible for the depression of molybdenite flotation. Other studies have shown that the precipitates formed in saline or seawater at $\mathrm{pH}>9.5$ dominated molybdenite depression. ${ }^{\mathbf{8 2 1 - 2 3}}$

Nevertheless, no generally accepted understanding of the influence of various salts has been available to explain why saline water improves or reduces molybdenite recovery. Most studies have indicated that the anisotropic features of molybdenite with van de Waal forces occurring within its basal planes (face) and Mo-S covalent bonds at edges ${ }^{11,13,24,25}$ play an important role in influencing molybdenite flotation. Lu, et al. ${ }^{26}$ 
investigated the anisotropic surface properties of molybdenite by direct surface force measurements using atomic force measurement (AFM) in $10 \mathrm{mM} \mathrm{NaCl}$ solution at various $\mathrm{pH}$ and concluded that the faces and edges of molybdenite displayed hydrophobic and hydrophilic features, respectively. They further postulated that small particles with a small face-edge ratio were less hydrophobic. Although many researchers have studied the surface properties of the face and edge of natural molybdenite, ${ }^{26-28}$ no convincing premise has been achieved to clearly explain salt effects on the faces and edges during flotation process.

To date, although several studies have attempted to investigate the influence of chlorides on molybdenite flotation, the roles and contributing effects of sulfate salts have not attracted sufficient attention..$^{5-7,29}$ As molybdenite is normally associated with other sulfide minerals, the oxidation of these sulfides in air or water would produce sulfate. In addition, the recycling of flotation water results in various cations in recycled solution. The accumulated cations and sulfates influence molybdenite flotation significantly. Furthermore, the flotation reagents that are normally applied to flotation process at least partially hide the effects of these cations on the natural flotability of molybdenite. Therefore, this work aimed to better understand the underlying flotation mechanisms of naturally hydrophobic molybdenite in the presence of sulfate salts (i.e. $\mathrm{Na}^{+}, \mathrm{K}^{+}, \mathrm{Ca}^{2+}$, and $\mathrm{Mg}^{2+}$ ) in the absence of flotation reagents.

\section{Materials and methods}

\subsection{Materials}

2.1.1 Molybdenite. The molybdenite used in this study was procured from Gui Lin, Guang Xi province, China. The bulk sample was crushed, ground and wet sieved to a particle size range of $38-75 \mu \mathrm{m}$. The prepared samples were then cleaned to remove fines, dried in a vacuum oven at $35{ }^{\circ} \mathrm{C}$ for $24 \mathrm{~h}$ and subsequently stored in a freezer to avoid oxidation prior to flotation. Fig. 1 shows the X-ray diffraction (XRD) analysis which indicates high purity and well-crystallized molybdenite mineral.

2.1.2 Reagents. $0.1 \mathrm{M} \mathrm{NaOH}$ and $\mathrm{HCl}$ solutions were used to adjust the slurry $\mathrm{pH}$. Analytical grade sodium sulfate

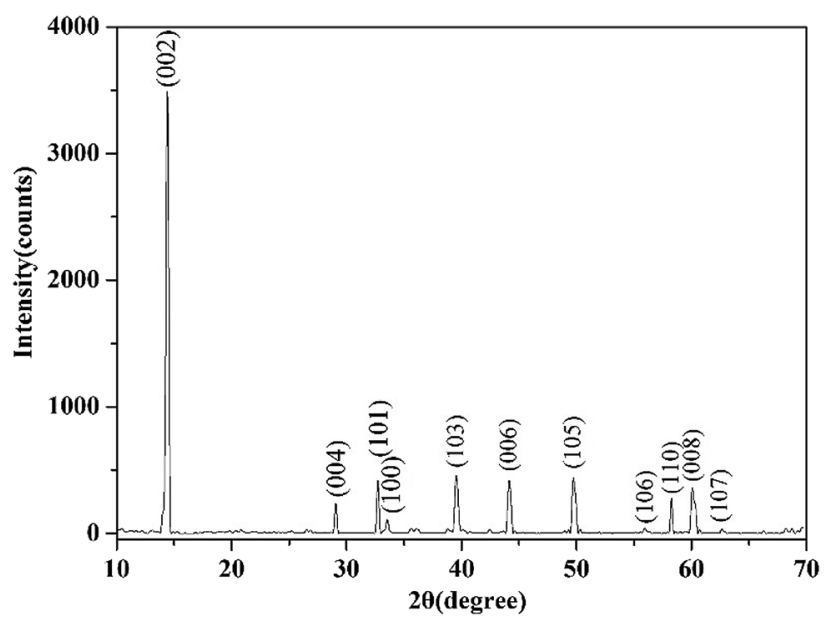

Fig. 1 XRD pattern of molybdenite sample.
$\left(\mathrm{Na}_{2} \mathrm{SO}_{4}\right)$, potassium sulfate $\left(\mathrm{K}_{2} \mathrm{SO}_{4}\right)$, calcium sulfate $\left(\mathrm{CaSO}_{4}\right)$ and magnesium sulfate $\left(\mathrm{MgSO}_{4}\right)$ were used to prepare the flotation solution with concentrations ranging from $10^{-4} \mathrm{M}$ to $10^{-2}$ M. De-ionized (DI) water was used for all flotation experiments whereas Millipore ${ }^{\circledR}$ ultrapure water with a resistivity of 18.2 $\mathrm{M} \Omega \mathrm{cm}$ was employed for all the measurements.

\subsection{Flotation experiments}

Mineral flotation tests were conducted using a hanging trough flotation machine (XFG, Wuhan Exploration Machinery Factory, China) with a $25 \mathrm{~mL}$ micro flotation cell, without (control) and with various concentrations of $\mathrm{Na}_{2} \mathrm{SO}_{4}, \mathrm{~K}_{2} \mathrm{SO}_{4}, \mathrm{CaSO}_{4}$, and $\mathrm{MgSO}_{4}$. $0.2 \mathrm{~g}$ molybdenite powder was conditioned in the flotation cell for $6 \mathrm{~min}$ and the pulp pH was adjusted using $0.1 \mathrm{M} \mathrm{NaOH}$ during this period. The froth products were collected every $10 \mathrm{~s}$ at 1, 3, 5, 8 and $10 \mathrm{~min}$ for $1 \mathrm{~min}$, at an airflow rate of $0.1 \mathrm{~L} \mathrm{~min}^{-1}$ at $1200 \mathrm{rpm}$. Froth concentrate and residue were collected and dried in a vacuum oven at $35{ }^{\circ} \mathrm{C}$ for $24 \mathrm{~h}$ and subsequently weighed to determine cumulative molybdenite recovery.

\subsection{Contact angle measurements}

Fresh molybdenite surfaces were obtained by peeling off the top layer of molybdenite sample. These surfaces were then conditioned in a salt solution for $6 \mathrm{~min}$. The sessile drop method (JC2000C1, Shanghai Zhongchen Digital Technology Company, China) was employed for contact angle measurements between molybdenite surface and a $0.25 \mu \mathrm{L}$ drop. ${ }^{29,30}$ Measurements were conducted in the $\mathrm{pH} 10$ solution with salt concentrations ranging from $10^{-4}$ to $10^{-2} \mathrm{M}$. The average of three different measurements was recorded as the final contact angle.

\subsection{Zeta potential measurements}

Zeta potential measurements (Zetasizer Nano-ZS90, Malvern Co., Ltd.) were conducted in simulated solution using $\mathrm{Na}_{2} \mathrm{SO}_{4}$, $\mathrm{K}_{2} \mathrm{SO}_{4}, \mathrm{CaSO}_{4}$, and $\mathrm{MgSO}_{4}$ at $10^{-4} \mathrm{M}, 10^{-3} \mathrm{M}$, and $10^{-2} \mathrm{M}$. A fresh molybdenite suspension $(-5 \mu \mathrm{m})$ was prepared and the $\mathrm{pH}$ was adjusted to $10 \mathrm{using} 0.1 \mathrm{M} \mathrm{NaOH} .{ }^{16,29}$ The average of three measurements was reported as the final zeta potential.

\subsection{Solution concentration analyses}

The solution concentrations were analysed by Inductively Coupled Plasma-Optical Emission Spectroscopy (Prodigy 7, Teledyne Leeman Labs, USA).

\section{Results}

\subsection{Effects of $\mathbf{p H}$}

Fig. 2 shows the $\mathrm{pH}$ influence on molybdenite flotation recovery in $0 \mathrm{M}$ and $10^{-2} \mathrm{M} \mathrm{Na}_{2} \mathrm{SO}_{4}$ solution for $3 \mathrm{~min}$ with $\mathrm{pH}$ ranging from 4 to 12 . The application of $10^{-2} \mathrm{M} \mathrm{Na}_{2} \mathrm{SO}_{4}$ solution improved molybdenite recovery in acidic medium but performed poorly under high alkaline conditions, compared to the absence of $\mathrm{Na}_{2} \mathrm{SO}_{4}(0 \mathrm{M})$. Molybdenite recovery was reached $91 \%$ in $10^{-2} \mathrm{M} \mathrm{Na}_{2} \mathrm{SO}_{4}$ at $\mathrm{pH} 4$, and gradually reduced to $89 \%$, $86 \%, 73 \%$ and $60 \%$ at $\mathrm{pH} 6,8,10$ and 12 , respectively. In the 


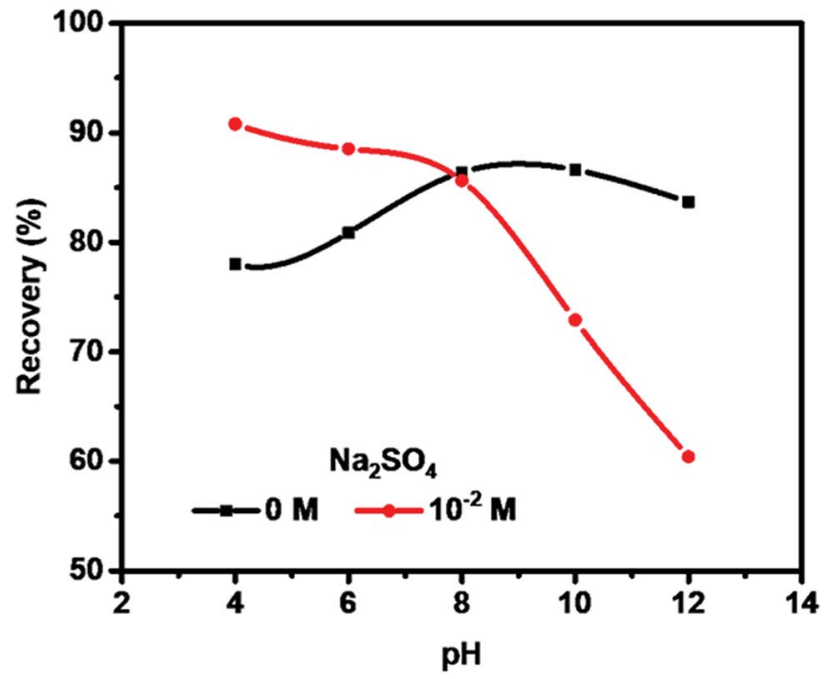

Fig. 2 Effects of pH on molybdenite recovery.

absence of $\mathrm{Na}_{2} \mathrm{SO}_{4}, 78 \%$ recovery was observed at $\mathrm{pH} 4$ which was increased to $87 \%$ at $\mathrm{pH} 8$. However, a further increase in $\mathrm{pH}$ resulted in reduced recovery, indicating an adverse effect under highly alkaline conditions. Considering that $\mathrm{pH} 10$ was normally used to depress pyrite flotation in molybdenite flotation plants, ${ }^{8,23}$ pH 10 was selected for further flotation.
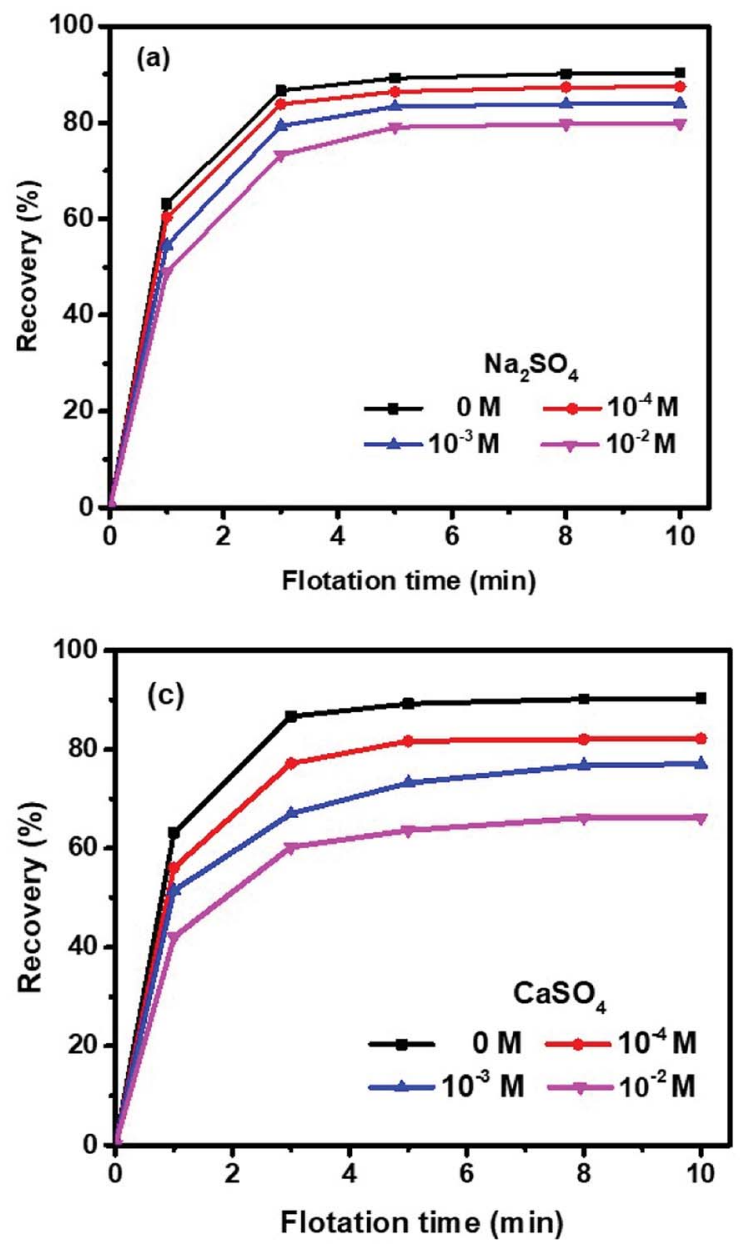

\subsection{Effects of sulfate salts}

Fig. 3 shows the cumulative molybdenite recovery as a function of flotation time in four sulfate salts within $10 \mathrm{~min}$. The molybdenite recovery was increased rapidly within the first $3 \mathrm{~min}$ but thereafter only a slight increase in recovery was observed up to 10 minutes. Specifically, a $90 \%$ recovery was achieved in the absence of sulfate salts, which agrees well with other studies. ${ }^{20,28}$ Molybdenite flotability was depressed to various extents in the presence of sulfate salts within the concentrations investigated in an order of $\mathrm{Mg}^{2+}>$ $\mathrm{Ca}^{2+}>\mathrm{K}^{+}>\mathrm{Na}^{+}$.

A recovery of $87 \%, 84 \%$, and $80 \%$ in $\mathrm{Na}_{2} \mathrm{SO}_{4}$ solution while $85 \%, 83 \%, 71 \%$ in $\mathrm{K}_{2} \mathrm{SO}_{4}$ solution was observed at $10^{-4}, 10^{-3}$ and $10^{-2} \mathrm{M}$, respectively, indicating that the presence of $\mathrm{K}^{+}$resulted in greater decrease in molybdenite flotability compared to $\mathrm{Na}^{+}$over the entire concentrations investigated (Fig. 3(a) and (b)). Moreover, as shown in Fig. 3(c) and (d), both $\mathrm{Ca}^{2+}$ and $\mathrm{Mg}^{2+}$ sulfates resulted in significantly greater negative effects on molybdenite recovery than either $\mathrm{Na}^{+}$or $\mathrm{K}^{+}$. Although a rapid flotation recovery was observed within $3 \mathrm{~min}$, the initial molybdenite recovered within this period was smaller in $\mathrm{Mg}^{2+}$ solution than that in $\mathrm{Ca}^{2+}$ solution. Clearly, the presence of $\mathrm{Mg}^{2+}$ resulted in greater depressions than $\mathrm{Ca}^{2+}$, dropping from $90 \%$ (without salts) to $79 \%, 68 \%, 59 \%$ and $82 \%, 77 \%, 66 \%$ when $\mathrm{Ca}^{2+}$ and $\mathrm{Mg}^{2+}$ were controlled at $10^{-4}, 10^{-3}$ and $10^{-2} \mathrm{M}$, respectively.
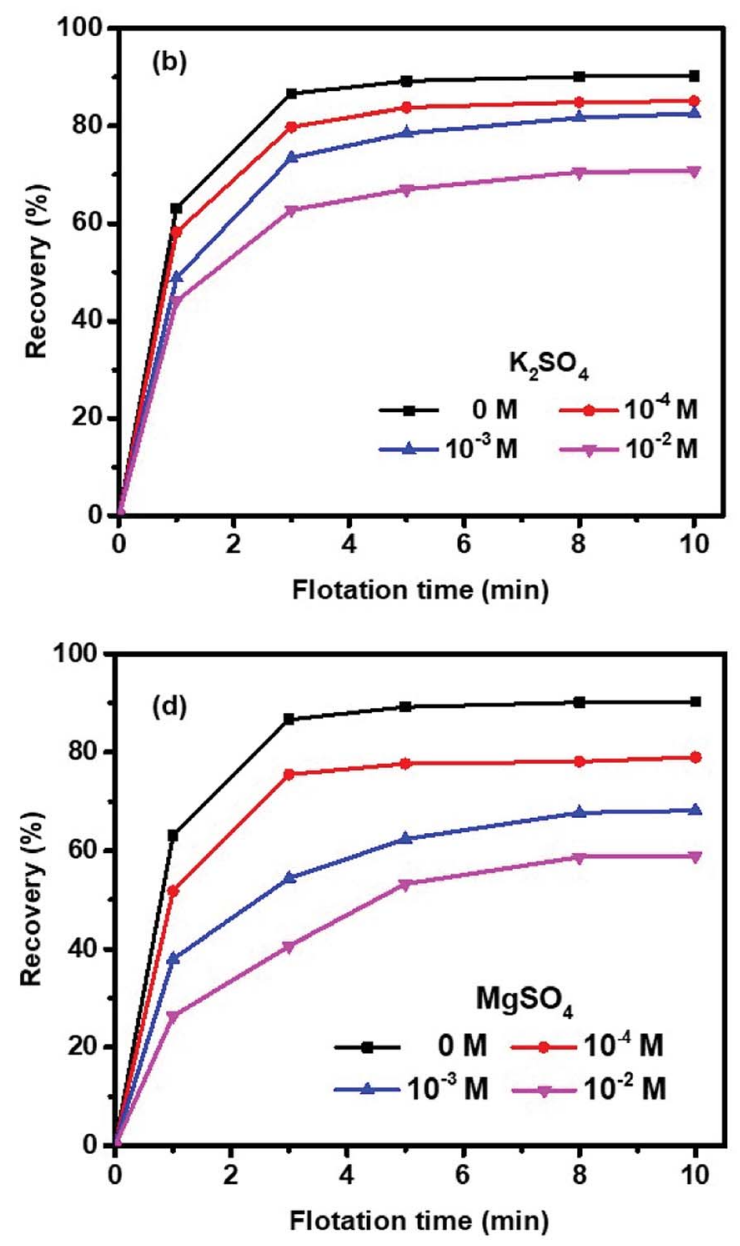

Fig. 3 Molybdenite recovery at pH 10: (a) $\mathrm{Na}_{2} \mathrm{SO}_{4}$, (b) $\mathrm{K}_{2} \mathrm{SO}_{4}$, (c) $\mathrm{CaSO}_{4}$, and (d) $\mathrm{MgSO}_{4}$. 
The classical first-order rate model,,$^{31-33}$ a generally accepted model for analyzing and interpreting flotation kinetics, was applied to determine the flotation rate constant of molybdenite, as shown in eqn (1):

$$
R=R_{\max }\left(1-\mathrm{e}^{(-k t)}\right)
$$

where $R$ is the recovery at time $t, R_{\max }$ is maximum recovery and $k$ is the flotation rate constant.

Fig. 4 shows the flotation kinetics of molybdenite in $10^{-4}$ to $10^{-2} \mathrm{M}$ sulfate solution. The rate constants $(k)$ of molybdenite flotation was decreased with increased sulfate concentration. In addition, with increased flotation time, the $k$ values were significantly decreased, indicating slower flotation rates during the latter flotation stage.

\subsection{Contact angle measurements}

Fig. 5 shows the contact angle measurements of molybdenite conditioned in $\mathrm{Na}_{2} \mathrm{SO}_{4}, \mathrm{~K}_{2} \mathrm{SO}_{4}, \mathrm{CaSO}_{4}$, and $\mathrm{MgSO}_{4}$ at pH 10. Prior to the addition of these salts, the fresh molybdenite surface exhibited was inherently hydrophobic with a contact angle of $89^{\circ}$, which agrees well with that reported previously. ${ }^{34} \mathrm{~A}$ gradual decrease in contact angle with increased sulfate salt
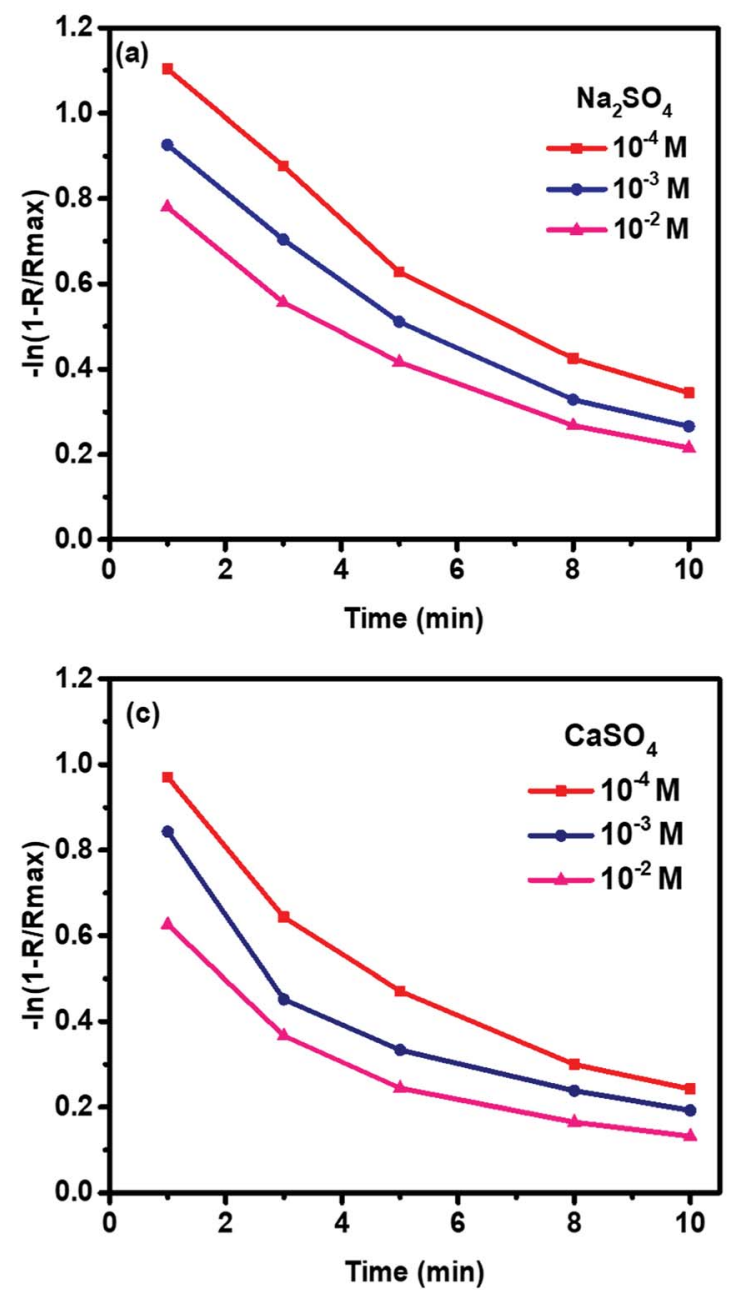

concentrations indicated that sulfate salts disrupted the natural hydrophobicity of molybdenite surface, with smaller contact angles being observed at greater sulfate concentrations. Final contact angles of $82.0^{\circ}, 80.8^{\circ}, 78.0^{\circ}$ and $77.5^{\circ}$ were observed for $10^{-2} \mathrm{M} \mathrm{Na}_{2} \mathrm{SO}_{4}, \mathrm{~K}_{2} \mathrm{SO}_{4}, \mathrm{CaSO}_{4}$ and $\mathrm{MgSO}_{4}$ solutions, respectively, showing an order of $\mathrm{MgSO}_{4}<\mathrm{CaSO}_{4}<\mathrm{K}_{2} \mathrm{SO}_{4}<\mathrm{Na}_{2} \mathrm{SO}_{4}$.

\subsection{Zeta potential measurements}

Fig. 6 shows the zeta potentials of molybdenite as a function of sulfate salt concentration at $\mathrm{pH}$ 10. The zeta potentials were negative for all salt concentrations investigated, similar to that reported in Hirajima, et al. ${ }^{8}$ In the absence of sulfate salts, the zeta potential was measured as $-32.6 \mathrm{mV}$, consistent with other studies. ${ }^{19,24}$ Clearly, the increased concentration of $\mathrm{Na}_{2} \mathrm{SO}_{4}$ and $\mathrm{K}_{2} \mathrm{SO}_{4}$ from $10^{-4}$ to $10^{-2} \mathrm{M}$ resulted in more negative molybdenite zeta potential values, e.g. $-41.2 \mathrm{mV},-62.6 \mathrm{mV},-66.6 \mathrm{mV}$ and $-41.0 \mathrm{mV},-60.1 \mathrm{mV},-65.65 \mathrm{mV}$ in $10^{-4}, 10^{-3}$ and $10^{-2} \mathrm{M}$ $\mathrm{Na}_{2} \mathrm{SO}_{4}$ and $\mathrm{K}_{2} \mathrm{SO}_{4}$ solutions, respectively.

In contrast, the zeta potentials in divalent sulfate solution became less negative with increasing sulfate salt concentrations. This effect was most pronounced for $\mathrm{MgSO}_{4}$ solutions with zeta potentials of $-25.2 \mathrm{mV},-19.1 \mathrm{mV}$ and $-10.3 \mathrm{mV}$ for
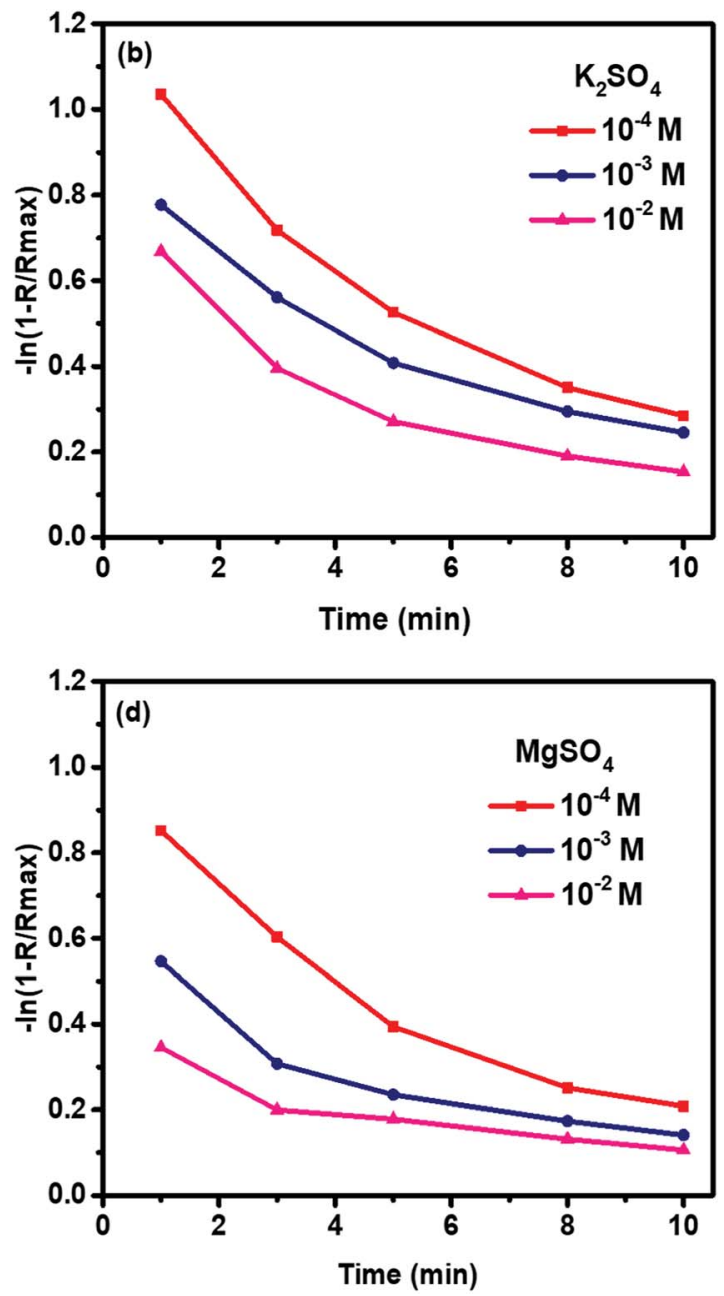

Fig. 4 Molybdenite flotation kinetics in $10^{-4}$ to $10^{-2} \mathrm{M}$ (a) $\mathrm{Na}_{2} \mathrm{SO}_{4}$, (b) $\mathrm{K}_{2} \mathrm{SO}_{4}$, (c) $\mathrm{CaSO}_{4}$, and (d) $\mathrm{MgSO}$ at $\mathrm{pH} 10$. 


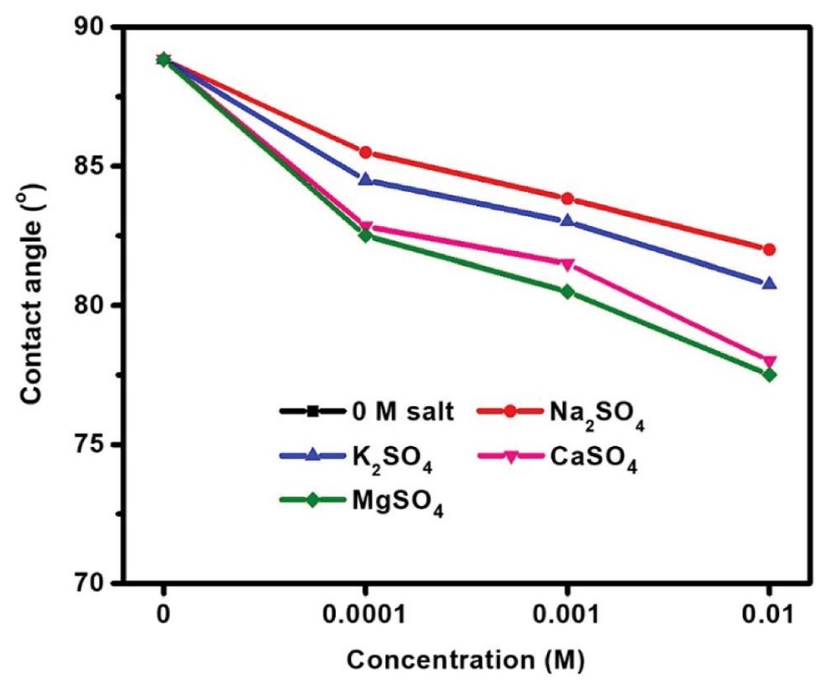

Fig. 5 Contact angle of molybdenite in sulfate solution at $\mathrm{pH} 10$.

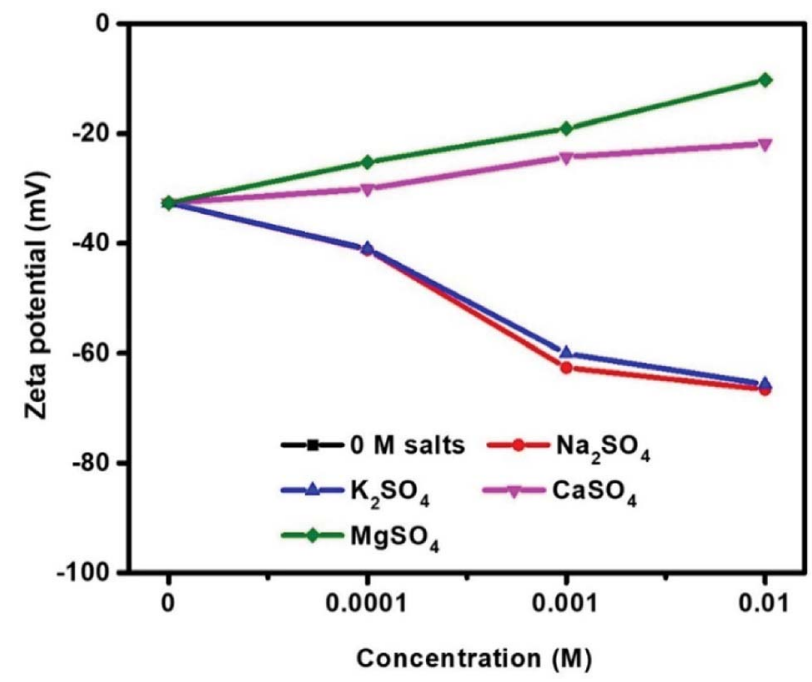

Fig. 6 Zeta potential of molybdenite in sulfate salts at pH 10.

$10^{-4}, 10^{-3}$ and $10^{-2} \mathrm{M}$ as compared to $-30.1 \mathrm{mV},-24.3 \mathrm{mV}$ and $-21.8 \mathrm{mV}$ for $\mathrm{CaSO}_{4}$ solutions.

\section{Discussion}

Most previous studies have only demonstrated negative effects due to chlorides, or $\mathrm{Ca}^{2+}$ and $\mathrm{Mg}^{2+}$ on molybdenite flotation, but have not examined sulfate, or $\mathrm{Na}^{+}$or $\mathrm{K}^{+}{ }^{6,20,22}$ This study, however, has examined the roles of four common sulfate salts existing in seawater or recycled water systems in mineral processing plants.

The flotation results as a function of $\mathrm{pH}$ (Fig. 2, 0 and $10^{-2} \mathrm{M}$ $\mathrm{Na}_{2} \mathrm{SO}_{4}$ ) agree well with results reported by Qiu, et al. ${ }^{6}$ who observed that molybdenite depression was started from $\mathrm{pH} 9.5$ on increasing $\mathrm{pH}$ with strong depression being observed at $\mathrm{pH} 11$ in seawater flotation. Lucay, et al. ${ }^{\mathbf{1 4}}$ reported a considerable repulsive force between molybdenite particles and bubbles in alkaline solution. The decrease in molybdenite flotability with increased $\mathrm{pH}$, in the presence of chloride salts, has been attributed to strong electric charge repulsive forces between molybdenite and air bubbles with increasing repulsion with increasing $\mathrm{pH}^{.35,36}$

In this study, the addition of all sulfates reduced flotation recovery in the absence of flotation reagents $\left(\mathrm{pH} 10,0\right.$ to $10^{-2} \mathrm{M}$, Fig. 3) with increasing depression in an order of $\mathrm{Mg}^{2+}>\mathrm{Ca}^{2+}>\mathrm{K}^{+}>$ $\mathrm{Na}^{+}$. The degree of depression was increased with increased sulfate concentration, probably due to the increased electrostatic repulsion between solid surfaces and air bubbles, similar to that in the chloride solution. Contact angle measurements (Fig. 5) were consistent with flotation results, e.g. increased surface wettability corresponded to reduced recovery. In contrast, less negative zeta potentials (Fig. 6) in the presence of $\mathrm{CaSO}_{4}$ and $\mathrm{MgSO}_{4}$ as compared to no salt addition indicated declining electrostatic repulsion, which should improve molybdenite flotability.

Some published works have indicated that molybdenite faces are not perfectly smooth, with hydrophilic micro-edges present on hydrophobic face. ${ }^{24,37,38}$ These micro-edges exhibit similar characteristics as molybdenite edges. ${ }^{\mathbf{1 4 , 2 0}}$ LópezValdivieso, et $a l .^{36}$ proposed that the faces of molybdenite particles were heterogeneous in nature with clusters of microcrystals, giving rise to nano-edges and nano-faces. Therefore, not only are the edges of molybdenite hydrophilic but also the hydrophobic surfaces contain hydrophilic micro-edges capable of adsorbing inorganic electrolytes, ${ }^{7,39}$ both resulting in detrimental effects on molybdenite flotation.

$\mathrm{Lu}$, et al. $^{26}$ reported that both surfaces and edges become more negatively charged under alkaline conditions, with the charge on the latter being relatively greater than the former. Wan, et al. ${ }^{20}$ recently reported that zeta potential of molybdenite was predominantly determined by the edges rather than faces, especially for fine particles. Moreover, compared to hydrophobic faces, molybdenite edges were more easily oxidized in solutions containing $\mathrm{O}_{2}$ and $\mathrm{OH}^{-}$to form, e.g., $\mathrm{MoO}_{4}{ }^{2-}$ and $\mathrm{HMoO}_{4}{ }^{-},{ }^{\mathbf{1 3 , 1 9}}$ according to eqn (2) and (3).

$$
\begin{gathered}
2 \mathrm{MoS}_{2}+9 \mathrm{O}_{2}+10 \mathrm{OH}^{-} \rightarrow 2 \mathrm{HMoO}_{4}{ }^{-}+4 \mathrm{SO}_{4}{ }^{2-}+4 \mathrm{H}_{2} \mathrm{O} \\
\mathrm{HMoO}_{4}{ }^{-}+\mathrm{OH}^{-} \rightarrow \mathrm{MoO}_{4}{ }^{2-}+\mathrm{H}_{2} \mathrm{O}
\end{gathered}
$$

The oxidation of molybdenite to produce $\mathrm{HMoO}_{4}{ }^{-}$normally occurs across the $\mathrm{pH}$ range of 2 to 6 , with increased $\mathrm{pH}, \mathrm{MoO}_{4}{ }^{2-}$ predominates. ${ }^{26,40}$ Therefore, $\mathrm{MoO}_{4}{ }^{2-}$ will be the primary oxidation products on molybdenite edges in the flotation process controlled at pH 10, as shown in Fig. 7(a).

Some studies have shown that the presence of $\mathrm{NaCl}$ and $\mathrm{KCl}$ improves molybdenite flotation. It has also been reported that both $\mathrm{Na}_{2} \mathrm{SO}_{4}$ and $\mathrm{K}_{2} \mathrm{SO}_{4}$ are beneficial to chalcopyrite oxidation/ leaching due to easier breakage of $\mathrm{S}-\mathrm{S}$ bonds when these two sulfates are available. ${ }^{41}$ Solubilised $\mathrm{Mo}$ in $0 \mathrm{M}$ and $10^{-2} \mathrm{M}$ $\mathrm{Na}_{2} \mathrm{SO}_{4}$, and $\mathrm{K}_{2} \mathrm{SO}_{4}$ was examined to understand the oxidation of molybdenite under flotation conditions. After $10 \mathrm{~min}$ flotation, the Mo concentrations were 797, 804, and $812 \mu \mathrm{g} \mathrm{L}^{-1}$, respectively, suggesting that $\mathrm{Na}_{2} \mathrm{SO}_{4}$ and $\mathrm{K}_{2} \mathrm{SO}_{4}$ increased molybdenite dissolution during flotation, with greater leaching being observed in $\mathrm{K}_{2} \mathrm{SO}_{4}$. This is consistent with flotation results shown in Fig. 3(a) and (b), i.e. the depressant effect due to $\mathrm{K}_{2} \mathrm{SO}_{4}$ was more significant than that of $\mathrm{Na}_{2} \mathrm{SO}_{4}$. Moreover, 


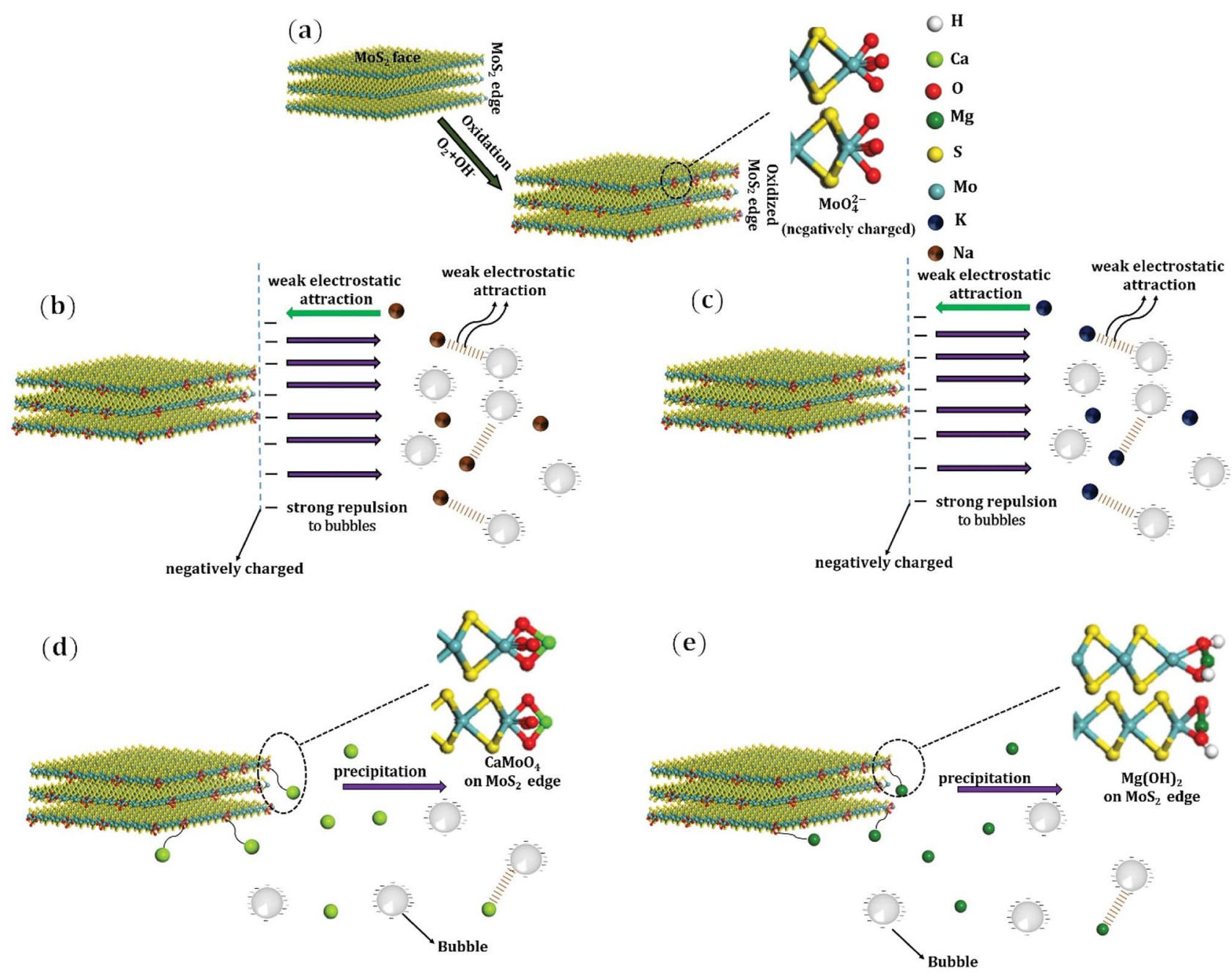

Fig. 7 Schematic of molybdenite oxidation and flotation in the presence of various cations. (a) Oxidised molybdenite edge, in the presence of (b) $\mathrm{Na}^{+}$, (c) $\mathrm{K}^{+}$, (d) $\mathrm{Ca}^{2+}$, and (e) $\mathrm{Mg}^{2+}$.

the oxidation/leaching occurring at micro-edges present on molybdenite faces or edges increased molybdenite wettability, consistent with contact angles shown in Fig. 4 and other studies. ${ }^{26}$ Therefore, the presence of $\mathrm{Na}_{2} \mathrm{SO}_{4}$ and $\mathrm{K}_{2} \mathrm{SO}_{4}$ catalysed surface oxidation, giving rise to more negative charges, i.e. more negative zeta potential (Fig. 6), consistent with those observed in Ozdemir, et al. ${ }^{42}$ In addition, more negative zeta potential of molybdenite leads to greater electrostatic repulsion between molybdenite surfaces and air bubbles which overrides the van der Waals and hydrophobic forces of attraction..$^{20,24}$

The mechanisms of flotation depression due to the presence of $\mathrm{CaSO}_{4}$ and $\mathrm{MgSO}_{4}$ are different from those due to $\mathrm{Na}_{2} \mathrm{SO}_{4}$ and $\mathrm{K}_{2} \mathrm{SO}_{4}$. As indicated in many other studies, ${ }^{8,29,39,43}$ the presence of $\mathrm{Ca}^{2+}$ and $\mathrm{Mg}^{2+}$ may result in precipitation, thereby depressing sulfide mineral flotation. Fig. 8(a) to (c) show that typical $\mathrm{Ca}^{2+}$ species present in $10^{-4} \mathrm{M}, 10^{-3} \mathrm{M}$ and $10^{-2} \mathrm{M} \mathrm{CaSO}_{4}$ solutions are $\mathrm{Ca}^{2+}, \mathrm{CaOH}^{+}$and $\mathrm{Ca}(\mathrm{OH})_{2(\mathrm{aq})}$ when the solution $\mathrm{pH}$ is less than 12. In addition, no Ca-containing precipitation is expected at $\mathrm{pH}$ 10. Notably, the molybdenite surface was less negatively charged (zeta potential measurements, Fig. 6) at pH 10 in the presence of $\mathrm{CaSO}_{4}$ suggesting both $\mathrm{Ca}^{2+}$ and $\mathrm{CaOH}^{+}$could have been adsorbed unto molybdenite edges or micro-edges, forming for instance $\mathrm{CaMoO}_{4}$. The adsorption of these species is likely to cover molybdenite edges and reduce its hydrophobicity, leading to decreased contact angles on increasing sulfate concentration (Fig. 5), in agreement with findings reported in López-Valdivieso, et $a .^{36}$ The stabilisation of liquid layer on less hydrophobic surface results in increased induction time for bubble-particle attachment, thereby decreasing molybdenite recovery ${ }^{44}$ consistent with that observed in Wan, et al. ${ }^{20}$

Fig. 8(d)-(f) show that the $\mathrm{pH}$ at which $\mathrm{Mg}(\mathrm{OH})_{2(\mathrm{~s})}$ precipitates decreases from $\mathrm{pH} 10.4$ to $\mathrm{pH} 9.4$ as $\mathrm{MgSO}_{4}$ concentration is increased from $10^{-4} \mathrm{M}$ to $10^{-2} \mathrm{M}$, in agreement with Hirajima, et al. ${ }^{8} \mathrm{Li}$ and Somasundaran ${ }^{39}$ observed that $\mathrm{Mg}(\mathrm{OH})_{2(\mathrm{~s})}$ precipitated with $\mathrm{pH}$ ranging from 9.2 to 11 where $\mathrm{Mg}^{2+}$ concentrations were decreased from $10^{-2}$ to $10^{-5} \mathrm{M}$. The adsorption of $\mathrm{Mg}(\mathrm{OH})_{2(\mathrm{~s})}$ onto molybdenite faces can make the hydrophobic surface to be hydrophilic, thereby depressing molybdenite flotation. $\mathrm{Mg}(\mathrm{OH})_{2}$ adsorbed onto molybdenite faces results in increased surface wettability and reduced molybdenite recovery under alkaline conditions. ${ }^{8}$ Therefore, the observed flotation depression in the presence divalent cation sulfate salts was associated with 

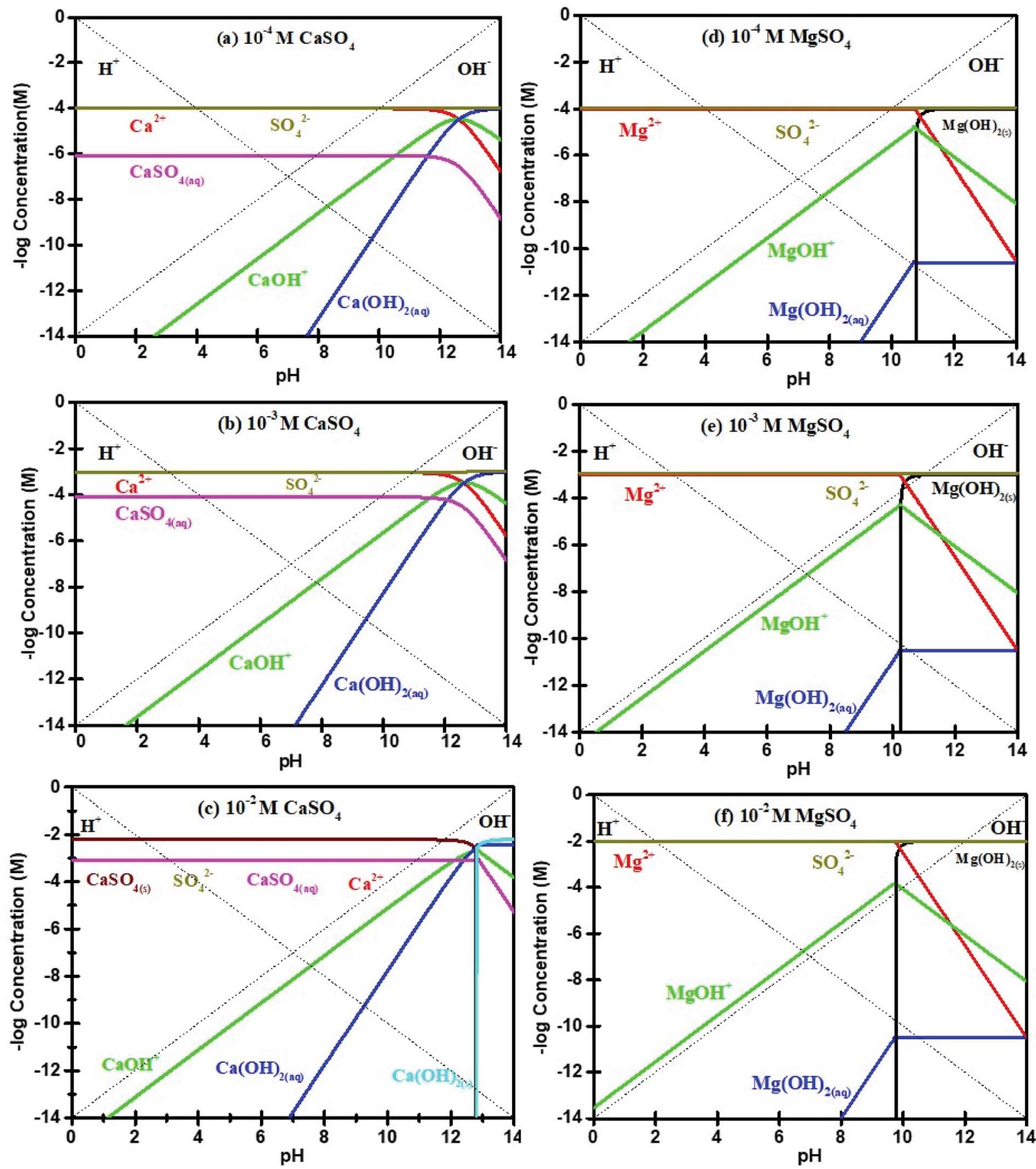

Fig. 8 Solution speciation diagrams for $\mathrm{Ca}^{2+}$ at concentrations of (a) $10^{-4} \mathrm{M}$, (b) $10^{-3} \mathrm{M}$ and (c) $10^{-2} \mathrm{M}$ and $\mathrm{Mg}^{2+}$ concentrations at (d) $10^{-4} \mathrm{M}$, (e) $10^{-3} \mathrm{M}$ and (f) $10^{-2} \mathrm{M}$

adsorption of hydrophilic and positive complexes and/or precipitation onto molybdenite surfaces..$^{2,22,23}$

\section{Conclusions}

The effects of four sulfate salts on molybdenite recovery were investigated. Both monovalent and divalent sulfate salts were detrimental to molybdenite flotability. The presence of $\mathrm{Na}^{+}$and $\mathrm{K}^{+}$ salts resulted increased molybdenite oxidation/leaching, most likely at the edges and micro-edges, resulting in more negative zeta potentials. The increased electrostatic repulsion between negatively charged bubble and molybdenite surface therefore decreaseed molybdenite recovery. However, in the presence of $\mathrm{Ca}^{2+}$ and $\mathrm{Mg}^{2+}$, the depressed molybdenite was attributed to the adsorption of positively charged complexes and/or precipitation of their hydroxides, e.g. the adsorption of $\mathrm{Ca}^{2+}, \mathrm{Ca}(\mathrm{OH})^{+}, \mathrm{Mg}(\mathrm{OH})^{+}$, $\mathrm{Mg}(\mathrm{OH})_{2}$. As the zeta potential of molybdenite was increased in the presence of $\mathrm{Ca}^{2+}$ and $\mathrm{Mg}^{2+}$, the edge species of $\mathrm{CaMoO}_{4}$ and the adsorption of $\mathrm{Mg}(\mathrm{OH})_{2}$ might predominate. 


\section{Conflicts of interest}

There are no conflicts to declare.

\section{Acknowledgements}

The authors acknowledge financial support from National Natural Science Foundation of China under projects of 51604205 and 51774223, Natural Science Foundation of Hubei Province (2016CFB268). The supports from Fundamental Research Funds for Central Universities (WUT: 2016 IVA046 and 2017IVB018) and undergraduate research foundation for independent innovation from Wuhan University of Technology (2017-ZH-A1-03 and 2017-ZH-C1-18) are gratefully acknowledged. In addition, Yingjie Li thanks the supports from Social Development Science and Technology Breakthrough Project of Shaanxi province (2015SF293).

\section{References}

1 G. Levay, R. S. C. Smart and W. Skinner, J. South. Afr. Inst. Min. Metall., 2001, 101, 69-75.

2 R. I. Jeldres, L. Forbes and L. A. Cisternas, Miner. Process. Extr. Metall. Rev., 2016, 37, 369-384.

3 J. Drelich and J. D. Miller, Water in Mineral Processing, 2012, pp. 73-85.

4 S. Castro and J. S. Laskowski, KONA Powder Part. J., 2011, 29, 4-15.

5 P. A. Moreno, H. Aral, J. Cuevas, A. Monardes, M. Adaro, T. Norgate and W. Bruckard, Miner. Eng., 2011, 24, 852-858.

6 Z. Qiu, G. Liu, Q. Liu and H. Zhong, Colloids Surf., A, 2016, 509, 123-129.

7 J. Laskowski, S. Castro and O. Ramos, Physicochem. Probl. Miner. Process., 2014, 50, 17-29.

8 T. Hirajima, G. P. W. Suyantara, O. Ichikawa, A. M. Elmahdy, H. Miki and K. Sasaki, Miner. Eng., 2016, 96, 83-93.

9 G. Bournival, R. Pugh and S. Ata, Miner. Eng., 2012, 25, 47-53. 10 M. Zhang, Y. Peng and N. Xu, Miner. Eng., 2015, 77, 93-98.

11 O. Ozdemir, Physicochem. Probl. Miner. Process., 2013, 49, 511-524.

12 J. Quinn, W. Kracht, C. Gomez, C. Gagnon and J. Finch, Miner. Eng., 2007, 20, 1296-1302.

13 S. Chander and D. Fuerstenau, Trans. Am. Inst. Min., Metall. Pet. Eng., 1972, 252, 62-69.

14 F. Lucay, L. Cisternas, E. Gálvez and A. López-Valdivieso, Miner. Metall. Process., 2015, 32, 203-208.

15 S. Castro, P. Rioseco and J. Laskowski, Proceedings of the 26th International Mineral Processing Congress, New Delhi, 2012.

16 A. Kasha, H. Al-Hashim, W. Abdallah, R. Taherian and B. Sauerer, Colloids Surf., A, 2015, 482, 290-299.

17 O. Ramos, S. Castro and J. Laskowski, Miner. Eng., 2013, 53, 108-112.

18 M. C. Fuerstenau, J. D. Miller and M. C. Kuhn, Chemistry of flotation, Society of Mining Engineers of American Institute of Mining, Metallurgical and Petroleum Engineers, 1985.

19 S. Raghavan and L. L. Hsu, Int. J. Miner. Process., 1984, 12, 145-162.
20 H. Wan, W. Yang, W. Cao, T. He, Y. Liu, J. Yang, L. Guo and Y. Peng, Minerals, 2017, 7, 141.

21 S. Castro, Water in Mineral Processing-Proceedings. of the First International Symposium, ed. J. Drelich, Society of Mining, Metallurgy, and Exploration, Seattle, WA, USA, 2012.

22 R. I. Jeldres, M. P. Arancibia-Bravo, A. Reyes, C. E. Aguirre, L. Cortes and L. A. Cisternas, Miner. Eng., 2017, 109, 10-13.

23 E. Rebolledo, J. S. Laskowski, L. Gutierrez and S. Castro, Miner. Eng., 2017, 100, 71-74.

24 J. O. Tabares, I. M. Ortega, J. R. Bahena, A. S. López, D. V. Pérez and A. L. Valdivieso, Proceedings of 2006 ChinaMexico Workshop on Minerals Particle Technology, San Luis Potosi, Mexico, 2006.

25 T. Hirajima, M. Mori, O. Ichikawa, K. Sasaki, H. Miki, M. Farahat and M. Sawada, Miner. Eng., 2014, 66, 102-111.

26 Z. Lu, Q. Liu, Z. Xu and H. Zeng, Langmuir, 2015, 31, 1140911418.

27 H. El-Shall, G. Zucker and K. Lofftus, Proceedings of the International Symposium on Electrochemistry in Mineral and Metal Processing, ed. P. E. Richardson, S. Srinivasan and R. Woods, 1984, pp. 96-111.

28 M. Zanin, I. Ametov, S. Grano, L. Zhou and W. Skinner, Int. J. Miner. Process., 2009, 93, 256-266.

29 Y. Li, W. Li, Q. Xiao, N. He, Z. Ren, C. Lartey and A. R. Gerson, Minerals, 2017, 7, 111.

30 E. Nowak, P. Robbins, G. Combes, E. H. Stitt and A. W. Pacek, Powder Technol., 2013, 250, 21-32.

31 S. Castro and E. Mayta, IV Meeting of the Southern Hemisphere on Mineral Technology, and III Latin American Congress on Froth Flotation, ed. S. Castro and J. Alvarez, Chile, 1994.

32 W. Chimonyo, K. Corin, J. Wiese and C. O'Connor, Miner. Eng., 2017, 110, 57-64.

33 B. Yang, S. Song and A. Lopez-Valdivieso, Physicochem. Probl. Miner. Process., 2015, 51, 181-189.

34 S. Kelebek, J. Colloid Interface Sci., 1988, 124, 504-514.

35 S. Castro, A. Lopez-Valdivieso and J. Laskowski, Int. J. Miner. Process., 2016, 148, 48-58.

36 A. López-Valdivieso, I. Madrid-Ortega, D. Valdez-Pérez, B. Yang and S. Song, Proceedings of the 9th International Mineral Processing Conference, 2012.

37 B. Triffett, C. Veloo, B. Adair and D. Bradshaw, Miner. Eng., 2008, 21, 832-840.

38 M. Komiyama, K. Kiyohara, Y. Li, T. Fujikawa, T. Ebihara, T. Kubota and Y. Okamoto, J. Mol. Catal. A: Chem., 2004, 215, 143-147.

39 C. Li and P. Somasundaran, J. Colloid Interface Sci., 1991, 146, 215-218.

40 P. Cannon and F. Norton, Nature, 1964, 203, 750-751.

41 Z. Wei, Y. Li, Q. Xiao and S. Song, Minerals, 2016, 6, 89.

42 O. Ozdemir, E. Taran, M. Hampton, S. Karakashev and

A. Nguyen, Int. J. Miner. Process., 2009, 92, 177-183.

43 D. Nagaraj and R. Farinato, Proceedings of the Processing Congress Presented at the XXVII International Mineral, Santiago, Chile, 2014.

44 G. P. W. Suyantara, T. Hirajima, A. M. Elmahdy, H. Miki and K. Sasaki, Colloids Surf., A, 2016, 501, 98-113. 